\section{INMR}

18,3

\section{2}

Received 8 August 2019 Revised 21 April 2020 12 August 2020

Accepted 14 January 2021

\title{
The quadruple and quintuple helix in innovation environments (incubators and science and technology parks)
}

\author{
Andrea Ap da Costa Mineiro \\ Graduate Program in Business Administration, \\ Federal University of Itajuba, Itajuba, Brazil and \\ Graduate Program in Business Administration, \\ Federal University of Lavras, Lavras, Brazil, and \\ Thais Assis de Souza and Cleber Carvalho de Castro \\ Graduate Program in Business Administration, \\ Federal University of Lavras, Lavras, Brazil
}

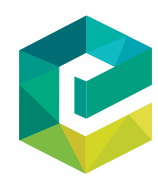

Innovation \& Management Review

Vol. 18 No. 3,2021

pp. $292-307$

pp. $292-307$
Emerald Publishing Limited Emerald P

DOI 10.1108/INMR-08-2019-0098

\begin{abstract}
Purpose - The purpose of this paper is to investigate the literature on the representation of the quadruple and quintuple helix (QQH) in innovation environments such as incubators and science and technology parks (STPS).

Design/methodology/approach - The authors used the integrative review as a methodological approach and systematized studies regarding the main research objectives; theoretical approaches; methodology and study object; QQH representation, by identifying actor, performance and main results; and additional contributions to the QQH model.

Findings - As a result, the authors noticed a lack of standardization on the representation of the quadruple helix, but the example of associations and community centers as representatives of the civil society. The quintuple helix does not have an actor that represents the environment, but STPs foster sustainable actions, encourage the generation of green companies and stimulate sustainable practices among established companies.

Originality/value - Based on changes in the economic and social scenarios, new theoretical approaches emerge to explain the innovation process, such as the QQH. Incubators and STPs are favorable settings for interactions, according to the new models; however, there is a lack of studies addressing this topic in such environments. Hence, this study contributes to understanding the existence and performance of $\mathrm{QQH}$, by showing how these new helices were identified, in addition to advancing the subject in innovation environments such as incubators and STPS.
\end{abstract}

Keywords Ambientes de inovação, Hélice quádrupla, Hélice quíntupla, Incubadoras,

Parques científicos e tecnológicos, Quadruple helix, Quintuple helix, Innovation habitats, Incubators, Science and technology parks

Paper type Literature review

(C) Andrea Ap da Costa Mineiro, Thais Assis de Souza and Cleber Carvalho de Castro. Published in Innovation \& Management Review. Published by Emerald Publishing Limited. This article is published under the Creative Commons Attribution (CC BY 4.0) licence. Anyone may reproduce, distribute, translate and create derivative works of this article (for both commercial and noncommercial purposes), subject to full attribution to the original publication and authors. The full terms of this licence maybe seen at http://creativecommons.org/licences/by/4.0/legalcode

The authors thank UNIFEI (Federal University of Itajubá) and UFLA (Federal University of Lavras), without which this research would not have been developed. 


\section{Introduction}

Innovation is one of the main factors of the current socioeconomic dynamics. Among the characteristics of innovation production is the interdependence between organizations and interdisciplinarity (Edquist, 2005; Machado, Lazzarotti, \& Bencke, 2018). Innovation processes are influenced by innovation habitats, which are spaces for collective learning; exchange of knowledge; and interaction among research centers, companies and government institutions, to carry out research that can be transferred to the production sector, assisting the region's economic development (Correia \& Gomes, 2012). Incubators quintuple helix and science and technology parks (STPs) are examples of these environments.

Both incubators and STPs are mechanisms to support innovation and regional development and are integrated to regional innovation ecosystems, together with educational and research institutions, and the public and private sectors (Associação Nacional de Entidades Promotoras de Empreendimentos Inovadores [Anprotec, 2012]). Etzkowitz and Zhou (2017) strengthen that STPs are spaces where the goals of economic and social development connect with science, market and civil society.

Incubators and STPs adopt a nonlinear model of innovation, the triple helix $(\mathrm{TH})$, which promotes interaction between different actors - university, industry and government (Etzkowitz \& Leydesdorff, 1995; Laguna \& Durán-Romero, 2017; Machado et al., 2018). Incubators are a challenge created by universities to foster collaboration with government and industry for the creation and development of innovation (Mulyaningsih, 2015). Yet, STPs create the ideal conditions to generate synergies between companies and research institutions, contributing to wealth creation. STPs are a type of corporate network, where proximity increases the cooperative relationships between companies and institutions (Farré-Perdiguer, Sala-Rios, \& Torres-Solé, 2016).

In addition to the existing relationships in the traditional triad university-industrygovernment, new social and economic concerns have led to rethinking the TH model (Pascoal \& Cabrita, 2016; Laguna \& Durán-Romero, 2017; Aranguren, Magro, Navarro, \& Wilson, 2018). New models emerged for innovation creation, including society (quadruple helix) and the environment (quintuple helix), as important helices in the dynamics of innovation.

Carayannis and Campbell (2009) observe that the quadruple helix model adds the perspectives of media and culture, as well as that of the organized civil society. In this helix, civil society is also perceived as an innovation user, acting as a driver of innovation processes (Arnkil, Järvensivu, Koski, \& Piirainen, 2010; Carayannis \& Rakhmatullin, 2014). In the quintuple helix, the environment is a major factor for humanity's preservation, survival and vitalization and must be present in the regional development policies and proposals (Carayannis, Barth, \& Campbell, 2012; Yoon, Yang, \& Park, 2017).

Some studies emphasize the need to understand new helices' approaches for STPs and incubators. Carayannis and Rakhmatullin (2014) state that the incubating process involves several partners that fit in the quadruple helix. Pascoal and Cabrita (2016) highlight that STPs face numerous challenges that led to new approaches and more complex support structures. Laguna and Durán-Romero (2017) emphasize that the literature is quite limited, regarding sustainability initiatives in STPs and the role they should play in promoting more sustainable strategies. Machado et al. (2018) and Hasche, Höglund, and Linton (2019) add that the challenging role of STPs consists of producing interactions to articulate the interests of the new agents present in the innovation models (quadruple and quintuple helix $[\mathrm{QQH}]$ ). From these considerations, the research problem emerged: how the new helices are considered in innovation environments such as incubators and STPs?

Thus, the aim of this article is to search the literature on the representation of the QQH in innovation environments, such as incubators and STPs. To do this, we systematized the studies 
INMR

18,3

to identify the main objectives of the research; the main theoretical approaches used; the methodology and study object; the representation of the $\mathrm{QQH}$, by identifying actor, performance and main results; and additional contributions to the $\mathrm{QQH}$ model in these innovation settings.

\section{Theoretical framework}

\subsection{Triple, quadruple and quintuple helix models}

The TH model has been widely used in the literature to focus on relationships among university, industry and government as a strategy to foster innovation dynamics. The TH model emerged as a framework for the analysis of knowledge-based innovation systems, emphasizing the multiple and reciprocal relationships among the three main actors in the process of knowledge creation and capitalization (Lombardi, Giordano, Farouh, \& Yousef, 2012).

$\mathrm{TH}$ considers the structure of reciprocal relationships among university, industry and government for knowledge creation and exchange to assist the promotion of innovation at regional or national level (Etzkowitz \& Leydesdorff, 1995, 2000). In this model of knowledge and innovation, each helix complies with its traditional function: universities provide creative researchers, companies convert research and creativity into products and innovation and governments contribute with legislation and financial support. In addition, one helix can play the role of another. The interaction and reciprocity between the three spheres are key elements of the innovation process (Etzkowitz, 2003; Laguna \& Durán-Romero, 2017).

New economic and social findings led to rethink the HT model and expand it with the addition of a new helix, considering the audience based on the media and culture (organized civil society) as a supporter of knowledge dissemination toward the knowledge society (Carayannis \& Campbell, 2009). Hence, the quadruple helix model (university-industrygovernment-society) strengthens the need for the knowledge economy to advance in parallel with the knowledge society (Carayannis et al., 2012; Laguna \& Durán-Romero, 2017).

In this helix, civil society is also an innovation user, acting as a driver of innovation processes. In this sense, users are essential to the model and encourage the development of innovations that are relevant to them (Arnkil et al., 2010; Carayannis \& Rakhmatullin, 2014). Arnkil et al. (2010) observe four different types of approaches to the quadruple helix:

(1) innovation user (consumer who assists companies in developing and improving products and services);

(2) laboratory centered on the company (company owns the innovation process, but society or users participate in the new knowledge);

(3) laboratory centered on the public sector (public institutions develop the innovation processes, to produce better services for society); and

(4) citizen (community or society with an essential role in the beginning of the innovation process). The central idea of this helix is the representation of the "other actors," who occupy a strategic position and have a leading role in the expression of their needs and demands within the social group (Lindberg, Danilda, \& Torstensson, 2012; Mulyaningsih, 2015; Aranguren et al., 2018).

In addition to the quadruple helix representation by Arnkil et al. (2010) and Carayannis and Campbell (2009), society may include distinct entities, such as financial organizations (Colapinto \& Porlezza, 2012), citizens and workers (Grundel \& Dahlstrom, 2016; Campanella, Peruta, Bresciani, \& Dezi, 2017), nongovernmental organizations or associations (Nordberg, 2015; Grundel \& Dahlstrom, 2016), groups (Mineiro, Castro, \& Amaral, 2019) or an arena with multiple actors (Hasche et al., 2019). 
Besides society, it is also necessary to consider environmental issues, to define a sustainability attribute. In recent years, environmental issues have become increasingly critical. Countries began to develop strategies and plans, seeking solutions for the problems of climate change and reduction of gas emissions to decrease the greenhouse effect (Chen, Chien, \& Hsieh, 2013). Under this wave, international society began to develop tools or indicators that could assess sustainable development (Chen, 2015). In this context, the quintuple helix has emerged (Carayannis \& Campbell, 2011; Casaramona, Sapia, \& Soraci, 2015).

As a transdisciplinary structure that includes the perspectives of sustainable development and social ecology, the quintuple helix model shows that it is essential to achieve a sustainable balance between the development paths of society and the economy, with their natural environments (ecology, knowledge and innovation) for the continuation of civilizations' progress (Carayannis \& Campbell, 2011).

Laguna and Durán-Romero (2017) argue that in a model of multiple helices, if a specific helix adopts steps toward sustainability, there will be a huge impact on the other helices and on the system as a whole. Thus, it is necessary to analyze the environments where these interactions may occur to generate a movement of positive influences.

\subsection{Innovation environments, society and sustainability}

Innovation habitats are multiple environments that favor innovation and are capable of intermediating the relationship between the innovation supplier and the receiving agent (Machado, Silva, Borba, \& Catapan, 2015). These innovation environments operate according to society's different interests, from the scientific-technological scenario to the basis of agriculture. Among these types of settings are business incubators and STPs, which are mechanisms integrated to local and regional innovation ecosystems, which provide support to innovation and to local and regional development (Anprotec, 2012; Machado et al., 2018).

Business incubators are spaces that support emerging businesses, by providing the development of entrepreneurial companies and helping them to survive and grow during the initial stage, when they are more vulnerable. They offer a backing structure, shared technical support with practical and professional guidance, assistance to entrepreneurs in their businesses' maturation through actions that strengthen the development of business management skills, in addition to supplying the venture with attributes essential to competitiveness (Anprotec, 2016).

Additionally, a business incubator is an important tool used by universities to support new innovative and sustainable start-ups and spin-offs and create links with industry, thus supporting the region's economic development (Bikse, Lusena-Ezera, Rivza, \& Volkova, 2016). Furthermore, an incubator is seen as a process that involves several partners. To identify these relevant partners, Carayannis and Rakhmatullin (2014) suggested the quadruple helix model. McAdam, Miller, and McAdam (2016) described some of the partners in an incubation process, among them academic entrepreneurs, workers of the Technology Transfer Institute, incubator's employees, industry financial supporters, policymakers, regional funders and innovation users.

Carayannis and Campbell (2010) and Bikse et al. (2016) observe that, in addition to contact with partners and society in the incubator, it is necessary to improve networking with different institutions, to ensure environment protection, by applying the quintuple helix model. This will provide eco-innovation and eco-entrepreneurship, which should be part of a broader concept of knowledge and innovation (Carayannis \& Campbell, 2010; Bikse et al., 2016).

Yet, STPs are the most advanced form of innovation environments (Zouain, Damião, \& Catharino, 2005). Their role is to create a setting that offers conditions for the innovation industry to rise, grow and add value to other economic sectors and to society as a whole. It is 
INMR

18,3

a model of concentration, connection, organization, articulation, implementation and promotion of innovative ventures aimed at strengthening this segment within a scenario of globalization and sustainable development (Anprotec, 2007).

STPs stimulate the flow of knowledge and technology between universities and companies; facilitate communication among companies, entrepreneurs and technicians; and provide an environment that strengthens the culture of innovation and creativity (Anprotec, 2012). The International Association of Science Parks and Areas of Innovation (IASP) (IASP, 2015) stresses that the innovation environments where STPs are established are highly specialized and have a key role in local development.

In addition to local development, STPs foster technological development, contribute to the creation and transfer of new technologies, help the growth of technology-based firms, participate in knowledge transfer between universities and companies and stimulate the development of innovative products and processes (Machado et al., 2018).

Furthermore, STPs can be catalysts for sustainable initiatives together with the university. The implementation of these initiatives in universities and in their STPS have resulted in interactions with the other helices, in a spillover effect that contributes to solve the challenges of sustainable development (Laguna \& Durán-Romero, 2017).

\section{Methodological procedures}

To answer the research question and attain the proposed objective, we developed this article from an integrative review. Starting from the systematization of search methods, we identified, selected and assessed studies critically, using them for collecting relevant data, thus bringing methodological rigor to the study (Broome, 1993; Botelho, Cunha, \& Macedo, 2011).

The integrative review method is useful for synthesizing the literature, hence supporting a comprehensive understanding on the representations of QQH in innovation environments, as well as generating new insights on the topic (Russell, 2005; Whittemore \& Knafl, 2005).

Based on Cooper (1998) and Whittemore and Knafl (2005), there are five methodological steps for building an integrative review. We present them together with the descriptions of research conducting:

(1) Step 1 - identification of the research question: At this stage, the researcher defines the question that will guide the search strategies. In our study, we sought to understand: how the new helices $(\mathrm{QQH})$ are represented in innovation environments such as incubators and STPs?

(2) Step 2 - literature search: An integrative review should cover relevant studies to support the search for answers to the central research question. To this end, academics define and develop research focuses that bring precision to the study, avoiding biases and inaccurate outputs. For this study, we searched articles in international and national bases, such as the main collection of the databases Web of Science (WOS), Scopus, Academic Search Premier - ASP (EBSCO), Science Direct, Scielo and Spell. We used the following terms for selecting the studies: "Quintuple_Helix" or "Quadruple_Helix" or "N-Tuple Helix" or "Multiple_Helix" and "Science_Park" or "Technology_Park" or "Research_Park" or "Science_and_Technology_Park" or "Science Technology Park" or "Incubator," in the topic field; that is, we searched these words in the articles' title, abstract and keywords. We used these English terms in international databases, and for the national bases, we translated the terms into Portuguese. Furthermore, in the Scopus, WOS and EBSCO databases, we used the trick characters $(*)$ to expand 
the search for similar terms. We considered the publication period until 2018 in Portuguese and English. Table 1 summarizes the studies found in each base. Altogether, we identified 19 studies.

(3) Step 3-evaluation of search results: At this qualitative stage, we selected relevant studies, based on inclusion and exclusion criteria defined to ensure data consistency. We adopted the following criteria for excluding articles: duplicity (seven excluded); availability (two excluded); and relevant to the topic (two excluded). Thus, we chose eight articles for full reading, shown in Table 2.

Quadruple and quintuple helix

Step 4 - data analysis: At this stage, we organized, explored, synthesized and classified data according to the research question. For this purpose, we developed a matrix for the studies' synthesis by using the Microsoft Excel ${ }^{\circledR}$ software. We collected the following data: general information on the article (title, authors' names, place and year of publication); objectives, introduction, approached theory, methodology used, study object, mode of data collection and analysis, $\mathrm{QQH}$ approach for the selected studies and final considerations (identifying actor,

\begin{tabular}{lccccr}
\hline Databases/helix theory & Quadruple & Quintuple & N-tuple & Multiple & Total \\
\hline WOS & 4 & 1 & 0 & 0 & 5 \\
Scopus & 5 & 3 & 0 & 1 & 9 \\
Science Direct & 2 & 0 & 0 & 0 & 2 \\
EBSCO & 2 & 1 & 0 & 0 & 3 \\
Scielo & 0 & 0 & 0 & 0 & 0 \\
Spell & 0 & 0 & 0 & 1 & 19 \\
Total & 13 & 5 & & 0
\end{tabular}

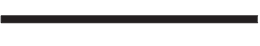
(1)

\section{Selected articles by} database

Selected articles

1 Schoonmaker, M. G., \& Carayannis, E. G. (2013). Mode 3: A proposed classification scheme for the knowledge economy and society. Journal of the Knowledge Economy, 4(4), 556-577

2 Mulyaningsih, H. D. (2015). Enhancing innovation in quadruple helix perspective: The case of the business incubators in Indonesia. International Business Management, 9(4), 367-371

3 Pascoal, A., \& Cabrita, M. R. (2016). Innovation ecosystems centered in EU-based science parks: Recent past and new trends. Proceedings of the 4th International Conference on Innovation and Entrepreneurship (ICIE) (pp. 367-373), Toronto

4 McAdam, M., Miller, K., \& McAdam, R. (2016). Situated regional university incubation: A multi-level stakeholder perspective. Technovation, 50-51, 69-78

5 Bikse, V., Lusena-Ezera, I., Rivza, B. \& Volkova, T. (2016). The transformation of traditional universities into entrepreneurial universities to ensure sustainable higher education. Journal of Teacher Education for Sustainability, 18(2), 75-88

6 Campanella, F., Peruta, M. R. D, Bresciani, S., \& Dezi, L. (2017). Quadruple helix and firms' performance: An empirical verification in Europe. Journal of Technology Transfer, 42(2), SI, 267-284

7 Laguna, N. E., \& Durán-Romero, G. (2017). Science parks approaches to address sustainability: A qualitative case study of the science parks in Spain. International Journal of Social Ecology and Sustainable Development, 8(3), 38-55

8 Machado, H. V., Lazzarotti, F., \& Bencke, F.F. (2018) Innovation models and technological parks: Interaction between parks and innovation agents. Journal of Technology Management and Innovation, 13(2), 104-114

Table 2.

Selected articles for integrative review 
INMR

18,3

\section{8}

performance and main results). After data collection, we categorized the results into the following steps: research objectives; main theoretical approaches used; methodology and study object; QQH representation (identifying actor, performance and main results); and additional contributions to QQH model in incubators and STPs. Therefore, we highlighted patterns and processes, as well as similarities and differences, which allowed us to refine the findings, by providing information that supported the discussions on the study's central goal.

(5) Step 5 - results presentation: At this stage, we presented an overview of all the material reviewed, showing a logical chain that validated the conclusions and discussions that resulted from the study.

\section{Results and analyses}

We organized the results according to the research objectives; main theoretical approaches used; methodology and study object; QQH representation, identifying the actor, performance and main results for each helix; and additional contributions to the QQH model.

Regarding the objectives of the examined studies, the pioneering study by Schoonmaker and Carayannis (2013) stands out; its proposal was to develop a classification structure for the knowledge economy and society. Using the Mode 3 of knowledge generation and the quadruple helix theory, the authors modeled corporate instances of networking between all the quadruple helix actors - university, government, industry and the organized civil society.

Several studies explore and search evidence of the quadruple or quintuple helix in the chosen environments, incubators or STPs (Mulyaningsih, 2015; Pascoal \& Cabrita, 2016; Laguna \& Durán-Romero, 2017; Machado et al., 2018). McAdam et al. (2016) used the theory of stakeholders and the quadruple helix to explore models of university incubation within regional and organizational characteristics and restrictions. Bikse et al. (2016) investigated problems related to the change of traditional universities into entrepreneurial universities, for offering sustainable higher education based on the quintuple helix. Finally, Campanella et al. (2017) applied the classification and regression analysis method to determine if a stronger relationship with innovation users (quadruple helix) had an effect on companies' profitability.

Next, we synthesized the theoretical approaches. The quadruple helix, proposed by Carayannis and Campbell (2009), represented by the organized civil society, is present in all articles. In addition, Schoonmaker and Carayannis (2013) consider that the organized civil society can be formal, as an institution, or virtual, which is a common value that actors of the innovation network keep. Mulyaningsih (2015) and Campanella et al. (2017) share the perception of Arnkil et al. (2010) that innovation users, who start and contribute to an integrated innovation system, represent the quadruple helix.

Regarding the quintuple helix, Laguna and Durán_Romero (2017) argue that there are two approaches: the first focuses on learning nature, to generate new knowledge by companies with green technologies; and the second focuses on the need to preserve the environment. They also highlight the multiple helices to represent the quintuple helix. For them, one actor affects all the others, and if universities' STPs engage in sustainable initiatives, there will be a spillover effect among the helices, which will contribute to solutions for the challenges of sustainable development (Laguna \& Durán-Romero, 2017).

Table 3 summarizes the main theoretical approaches used in the studies.

The IASP is the main reference for incubators and STPs. Pascoal and Cabrita (2016) strengthen the intermediation role played by STPs among academia, government 
organizations and private companies, formally or informally. Hence, they consider them as instruments for the promotion of regional development and reindustrialization.

In addition, there are theoretical approaches related to innovation (Mulyaningsih, 2015; Campanella et al., 2017; Machado et al., 2018); public innovation policies including the concept of S3 - strategies for smart specialization (Pascoal \& Cabrita, 2016); and clusters and innovation ecosystems (Mulyaningsih, 2015; Pascoal \& Cabrita, 2016) and regional innovation networks (Schoonmaker \& Carayannis, 2013). There are also approaches to university and knowledge, such as the entrepreneurial university (Bikse et al., 2016), quintuple helix university's third mission (Bikse et al., 2016; McAdam et al., 2016; Laguna \& Durán-Romero, 2017) and Mode 3 of knowledge generation (Schoonmaker \& Carayannis, 2013).

Regarding the methodology and study object, Table 4 summarizes the results.

Case studies prevail (five), with four single and one multiple, which is justified by the novelty of the theoretical field, confirmed by the date of the first study in these environments: Schoonmaker and Carayannis (2013), entitled "Mode 3: A proposed classification scheme for the knowledge economy and society," in the Journal of the Knowledge Economy.

Next, we analyzed the QQH approaches for incubators and STPs. Of the eight studies, six address the quadruple helix and three the quintuple helix. Regarding the quadruple helix, of the six cases examined, four regard STPs and two refer to incubators. As for the quintuple

\begin{tabular}{lcccc}
\hline Authors & Quadruple helix & Quintuple helix & Incubators or Technology Parks \\
\hline Schoonmaker and Carayannis (2013) & X & - & X \\
Mulyaningsih (2015) & X & - & X \\
Pascoal and Cabrita (2016) & X & - & X \\
McAdam et al. (2016) & X & - & X & X \\
Bikse et al. (2016) & - & X & X & Table 3. \\
Campanella et al. (2017) & X & - & X & approaches \\
Laguna and Durán-Romero (2017) & - & X & X \\
Machado et al. (2018) & X & X & & Main \\
\hline
\end{tabular}

\begin{tabular}{|c|c|c|c|}
\hline Authors & Methodology & Research object & \\
\hline $\begin{array}{l}\text { Schoonmaker and } \\
\text { Carayannis (2013) } \\
\text { Mulyaningsih (2015) }\end{array}$ & $\begin{array}{l}\text { Case study } \\
\text { (qualitative) } \\
\text { Case study } \\
\text { (qualitative) }\end{array}$ & $\begin{array}{l}\text { An incubator in Maryland (USA), a park in Portugal and an } \\
\text { "industry network" in Greece } \\
\text { Two incubators in Indonesia } \\
\text { Creative Community Association (CCA) } \\
\text { Community Development Center (CDC) }\end{array}$ & \\
\hline $\begin{array}{l}\text { Pascoal and Cabrita } \\
\text { (2016) }\end{array}$ & $\begin{array}{l}\text { Theoretical } \\
\text { essay }\end{array}$ & Science parks & \\
\hline McAdam et al. (2016) & $\begin{array}{l}\text { Case study } \\
\text { (qualitative) }\end{array}$ & $\begin{array}{l}\text { Two university incubators in the UK, one traditional and one } \\
\text { virtual }\end{array}$ & \\
\hline Bikse et al. (2016) & Survey & 80 managers of incubated firms & \\
\hline Campanella et al. (2017) & Survey & 4,215 companies located in STPs of 12 European countries & \\
\hline $\begin{array}{l}\text { Laguna and Durán- } \\
\text { Romero (2017) }\end{array}$ & $\begin{array}{l}\text { Case study } \\
\text { (multiple) }\end{array}$ & 12 STPs in Spain & Table 4. \\
\hline Machado et al. (2018) & $\begin{array}{l}\text { Theoretical } \\
\text { essay }\end{array}$ & Science parks & $\begin{array}{l}\text { Summary of the } \\
\text { methodology used }\end{array}$ \\
\hline
\end{tabular}


INMR

18,3

\section{0}

helix, two cases address STPs and one an incubator. Machado et al.'s proposal (2018) makes considerations on the QQH, and we used it in both analyses.

Through these approaches, we examined the actors that represented the QQHs, their performance and the main results associated to the helices. Actors related to the quadruple helix took different forms: community culture (Schoonmaker \& Carayannis, 2013); community represented by an association and a community center (Mulyaningsih, 2015); user (McAdam et al., 2016); no specific actor (Pascoal \& Cabrita, 2016); citizen (Campanella et al., 2017); and finally, society acting in co-innovation (Machado et al., 2018). This last study mentions three types of society:

(1) research and development (R\&D) agents, such as universities, companies and government;

(2) agents not related to R\&D, such as those involved in design, production, marketing, sales, technology, incremental changes, use of knowledge for new applications, interaction among, acquisition, patents, guarantees, etc.; and

(3) hybrid institutions, such as consortia, interdisciplinary research centers, support institutions (STPs and incubators) and funding institutions (venture capital, angel investment and seed money) (Machado et al., 2018).

Regarding the helix performance, some studies clearly highlight its operation, whereas others address its relevance. Schoonmaker and Carayannis (2013), McAdam et al. (2016) and Pascoal and Cabrita (2016) do not explain the performance of each helix but report situations where they were important. Schoonmaker and Carayannis (2013) address the community culture as the environment where the three actors (academia, government and industry) operate together to create innovation, that is, it regards TH. McAdam et al. (2016) strengthen that universities recognize the importance of collaborative relationships with industry and end users for increasing incubation's success. STPs are seen as actors capable of articulating several partners and fostering regional development in the quadruple helix (Pascoal \& Cabrita, 2016).

The studies by Mulyaningsih (2015), Campanella et al. (2017) and Machado et al. (2018) show a clearer performance of the quadruple helix. Mulyaningsih (2015) addresses it as a community with a leading role in attracting the innovation process, by creating demand for goods and services. The author studied two cases: Creative Community Association (CCA) and Community Development Center (CDC). In the case of CCA, it is at the center of the helices, with government and community being the dominant helices. In the case of CDC, industry is the dominant sector, and the center has the role of assisting the community. Campanella et al. (2017) observe that this helix was an explanatory variable to defend the importance of collaboration with users, consumers and citizens for creating innovation. Finally, for Machado et al. (2018), society participates in the innovation dynamics, including different forms of commercialization, and all actors create value within the innovation ecosystem. The authors show different types of interaction with society, such as job creation in the region; increase of local suppliers; scientific, cultural and sport activities; job creation at STP; networks with local firms; access to restaurants, shops in the park and leisure activities; and contracts with local companies.

Table 5 summarizes the main results for the quadruple helix.

We analyzed the same aspects in the studies involving the quintuple helix: the actor that represents the helix, its performance and the main results associated with the new helix. Recalling the information, of the three cases analyzed, two regarded STPs and one an incubator. 


\begin{tabular}{|c|c|c|}
\hline Authors & Results from the quadruple helix & uple and \\
\hline $\begin{array}{l}\text { Schoonmaker and } \\
\text { Carayannis (2013) }\end{array}$ & $\begin{array}{l}\text { Based on two methods for mapping the quadruple helix and knowledge } \\
\text { generation modes, authors noticed, in four Maryland firms, the ability to operate } \\
\text { within an innovation network that adopts the Mode } 3 \text { of knowledge generation. } \\
\text { These operate on the border of the quadruple helix, and one of them works in } \\
\text { partnership to seek R\&D }\end{array}$ & \\
\hline \multirow[t]{2}{*}{ Mulyaningsih (2015) } & \multirow{2}{*}{$\begin{array}{l}\text { In the case of CCA, the fourth helix (association) has a huge contribution in } \\
\text { fostering the strengthening and improvement of information and } \\
\text { communication technologies (ICTs) in the region; in supporting local } \\
\text { government for economic growth; and in providing ICT innovation for the } \\
\text { public service. As for CDC, the fourth helix (community center) plays an } \\
\text { essential role in creating community-based programs to boost ICT users and } \\
\text { strengthen the innovation ecosystem through technology, considering the } \\
\text { community both as beneficiary and market, creating needs and receiving } \\
\text { demands for community's goods and services }\end{array}$} & 301 \\
\hline & & \\
\hline Pascoal and Cabrita (2016) & $\begin{array}{l}\text { The authors proposed three distinct roles for the new generation of STPs: } \\
\text { ecosystem for innovation pilots; key-actor of the quadruple helix model; and } \\
\text { connectivity and external appearance }\end{array}$ & \\
\hline McAdam et al. (2016) & $\begin{array}{l}\text { It was evident that the differences in the incubation processes at the two } \\
\text { universities were caused by their culture, internal mechanisms and engagement } \\
\text { with partners of the quadruple helix. Case } 1 \text { adopted a traditional model of } \\
\text { incubator, whereas Case } 2 \text { chose a model of virtual incubator that meets the } \\
\text { requirements and allows more interaction among the actors. The situation of the } \\
\text { incubators is in contrast to the recent policy that identifies the need for the } \\
\text { quadruple helix partners to work in collaboration, to reach a stage of high } \\
\text { interdependence and help co-creating innovative ecosystems, thus improving } \\
\text { regional development. In the cases studied, there is dependency among the } \\
\text { actors, with a strong influence from the university }\end{array}$ & \\
\hline Campanella et al. (2017) & $\begin{array}{l}\text { In STPS, "the Quadruple Helix" (user) has an important role in classifying firms } \\
\text { with the highest performance. The empirical analysis highlighted that a high } \\
\text { return on investment for firms in STPs happens with: companies that give great } \\
\text { importance to collaboration with users, consumers and citizens for creating their } \\
\text { innovation; companies that attach great importance to collaboration with } \\
\text { private financial institutions to fund innovation; and companies that provide } \\
\text { product innovation }\end{array}$ & \\
\hline Machado et al. (2018) & $\begin{array}{l}\text { Relevance of STPs' role for the success of innovation models that have } \\
\text { integrating functions with the community and the natural environment. It } \\
\text { should be considered that interaction between agents and STPs is established } \\
\text { through collaboration mechanisms and moderation of conflicts }\end{array}$ & $\begin{array}{r}\text { Table } 5 . \\
\text { Results of the } \\
\text { quadruple helix }\end{array}$ \\
\hline
\end{tabular}

Regarding the representation of the quintuple helix, none of the studies identified an actor (Bikse et al., 2016; Laguna \& Durán-Romero, 2017; Machado et al., 2018). Bikse et al. (2016) report the incubator's sustainable assumptions. Laguna and Durán-Romero (2017) strengthen that STPs are drivers of sustainable public policies and disseminators of sustainable practices among companies; and Machado et al. (2018) associate the helix to the natural environment and eco-entrepreneurship.

As for the performance, Bikse et al. (2016) mention that the objective of Kurzeme Business Incubator (KBI) incubator is to promote and support eco-entrepreneurship in some sectors of the national economy. Laguna and Durán-Romero (2017) show that the responsibility of STPs with sustainability comes first from the interaction with universities (committed to sustainable development) and takes multiple forms. Among the different attributions assumed, the following stand out: 
INMR

18,3

\section{2}

- reduction of the initial environmental impact of real estate initiatives;

- promotion of sustainable practices in spin-offs, start-ups and all related companies;

- incentive to the development of sustainable innovations that face environmental deterioration (green growth technologies);

- influence on green growth, by disseminating a sustainable strategic culture to associated companies (being environmentally conscious has a positive effect on organizations' reputation, given the increasing acceptance of sustainability in society); and

- additional role as a generator of sustainable knowledge spillovers, used by associated companies in their surroundings. Machado et al. (2018) mention that this helix operates in sustainable development.

Among the forms of interaction with the environment, the authors highlight:

- incentives for ecological innovation;

- incentives for eco-entrepreneurship;

- preservation of natural resources;

- activities aimed at sustainable development;

- improvement of the quality of life; and

- promotion of culture and social values.

Table 6 summarizes the main results for the quintuple helix.

Finally, regarding the additional contributions to the $\mathrm{QQH}$ model in these innovation environments, Table 7 presents their synthesis.

Additional contributions help understanding how incubators and STPs perceive QQH and can be instruments for future studies that seek to identify the existence of $\mathrm{QQH}$ in their innovation environments.

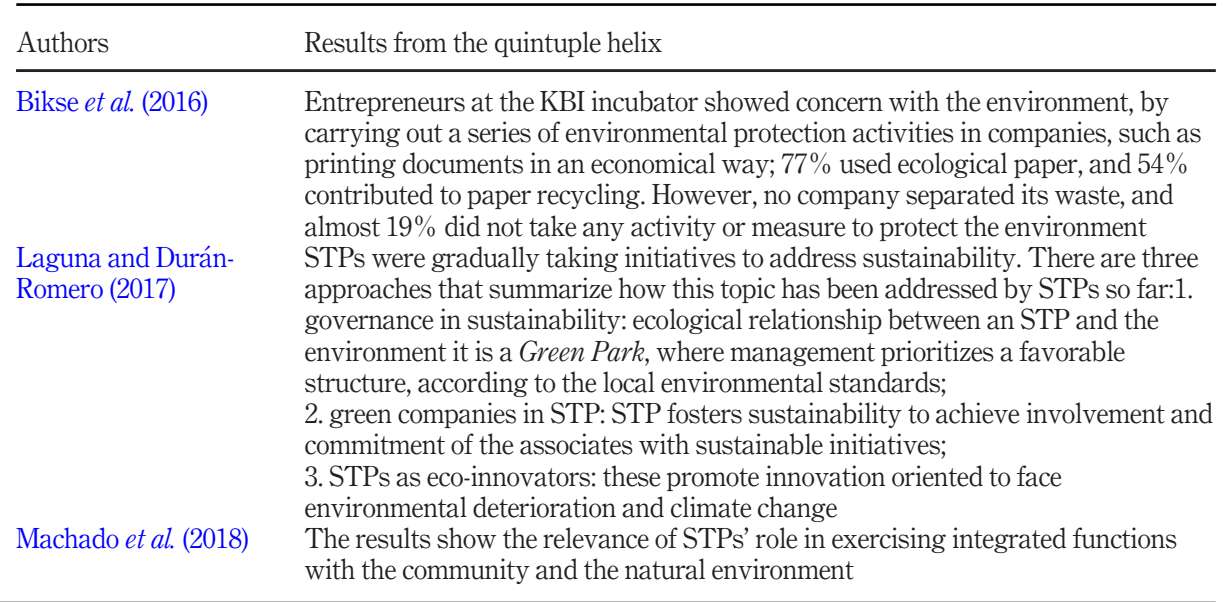

Table 6.

Results from quintuple helix

Machado et al. (2018)

Entrepreneurs at the KBI incubator showed concern with the environment, by carrying out a series of environmental protection activities in companies, such as printing documents in an economical way, $77 \%$ used ecological paper, and $54 \%$ almost $19 \%$ did not take any activity or measure to protect the environment STPs were gradually taking initiatives to address sustainability. There are three approaches that summarize how this topic has been addressed by STPs so far:1. governance in sustainability: ecological relationship between an STP and the environment it is a Green Park, where management prioritizes a favorable structure, according to the local environmental standards; 2. green companies in STP: STP fosters sustainability to achieve involvement and commitment of the associates with sustainable initiatives;

3. STPs as eco-innovators: these promote innovation oriented to face The resut show the re with the community and the natural environment 


\begin{tabular}{|c|c|c|}
\hline Authors & Additional contributions from $\mathrm{QQH}$ & in \\
\hline $\begin{array}{l}\text { Schoonmaker and } \\
\text { Carayannis (2013) }\end{array}$ & $\begin{array}{l}\text { The authors used two methods to understand the structure of Mode } 3 \text { of the } \\
\text { quadruple helix: to model the involvement of all actors in the quadruple helix, } \\
\text { together with the corresponding modes - Mode } 1 \text {, Mode } 2 \text { and Mode } 3 \text { (this is } \\
\text { where the quadruple helix is); to evaluate the quadruple helix according to the } \\
\text { structure of critical success factors (R\&D sources, access to funding and support } \\
\text { programs), offered to new firms inside a regional innovation network } \\
\text { The CCA case identified some factors on the role of the quadruple helix. }\end{array}$ & 303 \\
\hline Mulyaningsih (2015) & $\begin{array}{l}\text { (1) the starter of the innovation process is the community, which plays the main } \\
\text { role as owner of the whole innovation process; } \\
\text { (2) the main objective of its innovation activity is to provide talented and } \\
\text { productive people with an innovation ecosystem for designing new products, } \\
\text { especially of ICT; its operation carries out programs to improve the capacity of } \\
\text { its members with managerial training for the advanced start-up business; and } \\
\text { (3) the type of innovation is incremental, related to the need of its user or } \\
\text { customer } \\
\text { On the other hand, the CDC center plays a role in facilitating communities' } \\
\text { building, dividing its action in three main programs: access community, content } \\
\text { community and community development }\end{array}$ & \\
\hline McAdam et al. (2016) & $\begin{array}{l}\text { Although recognizing the importance of the quadruple helix, some factors } \\
\text { highlight the difficulties for the helices to interact, such as: } \\
\text { (i) the institutional and organizational context of the university, which can } \\
\text { prevent industry and end users from being considered as partners; } \\
\text { (ii) geographic location in a peripheral region; and } \\
\text { (iii) the lack of financial incentives to encourage collaboration among the actors }\end{array}$ & \\
\hline $\begin{array}{l}\text { Laguna and Durán-- } \\
\text { (2017) }\end{array}$ & $\begin{array}{l}\text { oThe authors used a theoretical model to analyze the sustainability of STPs, } \\
\text { focusing on four pillars: } \\
\text { (1) strategic management of sustainability; } \\
\text { (2) specialization in sustainability; } \\
\text { (3) environmental consciousness; and } \\
\text { (4) associates' sustainable entrepreneurship }\end{array}$ & $\begin{array}{r}\text { Table } 7 . \\
\text { Additional } \\
\text { contributions from } \\
\mathrm{QQH}\end{array}$ \\
\hline
\end{tabular}

\section{Final remarks}

This article investigated the literature on the representation of the QQH in innovation environments, such as incubators and STPs. For that purpose, we systematized the studies to identify the main objectives of the research; the main theoretical approaches adopted; methodology and study object; QQH representation, identifying actor, performance and main results; and additional contributions to the $\mathrm{QQH}$ model in these settings.

Regarding the studies' objectives, $50 \%$ sought to understand the operation of the new helices in incubators and STPs, whereas the others considered this approach as an additional proposal.

As for the theoretical approach, there are more studies related to the quadruple helix and STPs. The proposal by Carayannis and Campbell (2009) and Arnkil et al. (2010) on the quadruple helix prevails, as an organized civil society and innovation user, respectively. However, there is evidence of a formal and a virtual society. In the quintuple helix, Laguna and Durán-Romero (2017) add two approaches, one focused on green companies and the other on the need to preserve the environment. Furthermore, in these studies, theories relate to innovation, public policies, innovation ecosystems, networks and the entrepreneurial university. 
INMR 18,3

Regarding the methodological proposals, there is a concentration of exploratory qualitative studies, justified by the novelty of the topic. There is also a concentration of studies in European countries.

In the quadruple helix approach, we noticed the absence of standardization regarding who represents the society, which was identified as society, community, citizen and without identification. However, the most concrete representation was the one that associated the quadruple helix to a society and community, with the role of fostering and supporting the development of innovation. Society was seen in an active and passive way, acting and promoting innovation, as well as receiving the benefits of the innovation environments, respectively. Regarding the results of the quadruple helix, the focus was to understand who the players are and how they act in their contexts.

Yet, regarding the quintuple helix, there was a similarity among the studies in not identifying a representative, but instead the actions that foster sustainable development. Among the results, there were sustainable actions done by entrepreneurs and those developed by STPs managers.

The additional approaches complement the understanding of the $\mathrm{QQH}$, bringing information on the functionalities and challenges of the quadruple helix, in addition to a theoretical structure of the quintuple helix.

Our study contributes to understand the existence and operation of $\mathrm{QQH}$, shows how the new helices were identified, in addition to advancing the topic for innovation environments such as incubators and STPS.

Regarding its limitations, we mention the low number of studies in the area, considering the topic's newness, and the lack of approaches for other innovation environments. Hence, we suggest as future work a new search in other scientific bases and the analysis of other environments such as accelerators and innovation hubs. In addition, we propose an empirical analysis of $\mathrm{QQH}$ actors in national innovation environments, to identify their representation and operationalization.

\section{References}

Anprotec (2007). Parques tecnológicos no Brasil - Estudo, análise e proposições. Brasília: Anprotec and ABDI. Retrieved from https://anprotec.org.br/site/publicacoes-anprotec/estudos-e-pesquisas/ parques-tecnologicos-no-brasil-estudo-analisee-proposicoes_2007/

Anprotec (2012). Estudo, análise e proposições sobre as incubadoras de empresas no Brasil (relatório técnico). Brasilia: Ministério da Ciência, Tecnologia e Inovação and Anprotec. Retrieved from https://anprotec. org.br/site/wp-content/uploads/2020/06/Estudo_de_Incubadoras_Resumo_web_22-06_FINAL_pdf_59. pdf

Anprotec (2016). Estudo de impacto econômico: Segmento de incubadoras de empresas do Brasil (relatório técnico). Brasília: Anprotec. Retrieved from https://anprotec.org.br/site/wp-content/ uploads/2020/06/18072016-Estudo_ANPROTEC_v6.pdf

Aranguren, M. J., Magro, E., Navarro, M., \& Wilson, J. R. (2018). Governance of the territorial entrepreneurial discovery process: Looking under the bonnet of RIS3. Regional Studies, 53(4), 451-461, doi: https://doi.org/10.1080/00343404.2018.1462484.

Arnkil, R., Järvensivu, A., Koski, P., \& Piirainen, T. (2010). Exploring quadruple helix outlining useroriented innovation models. Finland: University of Tampere. Retrieved from https:/trepo.tuni.fi/ bitstream/handle/10024/65758/978-951-44-8209-0.pdf?sequence=1

Bikse, V., Lusena-Ezera, I., Rivza, B., \& Volkova, T. (2016). The transformation of traditional universities into entrepreneurial universities to ensure sustainable higher education. Journal of Teacher Education for Sustainability, 18(2), 75-88, doi: https://doi.org/10.1515/jtes-2016-0016. 
Botelho, L. L. R., Cunha, C. C. A., \& Macedo, M. (2011). O método da revisão integrativa nos estudos organizacionais. Gestão e Sociedade, 5(11), 121-136, doi: https://doi.org/10.21171/ges.v5i11.1220.

Broome, M. E. (1993). Integrative literature reviews for the development of concepts. In B. L. Rodgers, \& K. A. Knafl, (Eds.), Concept development in nursing (2nd ed., pp. 231-250). Philadelphia, PA: W. B. Saunders Co.

Campanella, F., Peruta, M. R. D., Bresciani, S., \& Dezi, L. (2017). Quadruple helix and firms' performance: An empirical verification in Europe. The Journal of Technology Transfer, 42(2), 267-284, doi: https://doi.org/10.1007/s10961-016-9500-9.

Carayannis, E. G., \& Campbell, D. F. (2009). '"Mode 3"' and “'quadruple helix”": Toward a 21st century fractal innovation ecosystem. International Journal of Technology Management, 46(3/4), 201-234, doi: https://doi.org/10.1504/IJTM.2009.023374.

Carayannis, E. G., \& Campbell, D. F. J. (2010). Triple helix, quadruple helix and quintuple helix and how do knowledge, innovation and the environment relate to each other? A proposed framework for a transdisciplinary analysis of sustainable development and social ecology. International Journal of Social Ecology and Sustainable Development, 1(1), 41-69, doi: https://doi.org/10.4018/ jsesd.2010010105.

Carayannis, E. G., \& Campbell, D. F. (2011). Open innovation diplomacy and a 21st century fractal research, education and innovation (FREIE) ecosystem: Building on the quadruple and quintuple helix innovation concepts and the "mode 3" knowledge production system. Journal of the Knowledge Economy, 2(3), 327-372, doi: https://doi.org/10.1007/s13132-011-0058-3.

Carayannis, E. G., \& Rakhmatullin, R. (2014). The quadruple/quintuple innovation helixes and smart specialisation strategies for sustainable and inclusive growth in Europe and beyond. Journal of the Knowledge Economy, 5(2), 212-239, doi: https://doi.org/10.1007/s13132-014-0185-8.

Carayannis, E. G., Barth, T. D., \& Campbell, D. F. (2012). The quintuple helix innovation model: Global warming as a challenge and driver for innovation. Journal of Innovation and Entrepreneurship, 1(1), 1-12, doi: https://doi.org/10.1186/2192-5372-1-2.

Casaramona, A., Sapia, A., \& Soraci, A. (2015). How TOI and the quadruple and quintuple helix innovation system can support the development of a new model of international cooperation. Journal of the Knowledge Economy, 6(3), 505-521, doi: https://doi.org/10.1007/s13132-015-0253-8.

Chen, H. (2015). Using water footprints for examining the sustainable development of science parks. Sustainability, 7(5), 5521-5541, doi: https://doi.org/10.3390/su7055521.

Chen, H., Chien, L., \& Hsieh, T. (2013). A study of assessment indicators for environmental sustainable development of science parks in Taiwan. Environmental Monitoring and Assessment, 185(8), 7001-7012, doi: https://doi.org/10.1007/s10661-013-3080-z.

Colapinto, C., \& Porlezza, C. (2012). Innovation in creative industries: From the quadruple helix model to the systems theory. Journal of the Knowledge Economy, 3(4), 343-353, doi: https://doi.org/ 10.1007/s13132-011-0051-x.

Cooper, H. M. (1998). Synthesizing research: A guide for literature reviews (3rd ed.). Thousand Oaks, CA: Sage Publications.

Correia, A. M. M., \& Gomes, M. L. B. (2012). Habitats de inovação na economia do conhecimento: Identificando ações de sucesso. Revista de Administração e Inovação, 9(2), 32 -54, doi: https://doi. org/10.5773/rai.v9i2.673.

Edquist, C. (2005). Systems of innovation perspectives and challenges. In J. D. C. Mowery, \& R. R. Nelson, (Eds.), The oxford handbook of innovation (pp. 181-207). Oxford: Oxford University Press.

Etzkowitz, H. (2003). Innovation in innovation: The triple helix of university-industry-government relations. Social Science Information, 42(3), 293-337, doi: https://doi.org/10.1177\%2F05390184030423002.

Etzkowitz, H., \& Leydesdorff, L. (1995). The triple helix - University-industry-government relations: A laboratory for knowledge based economic development. EASST Review, 14(1), 14-19. Retrieved from https:/papers.ssrn.com/sol3/papers.cfm?abstract_id=2480085 
INMR 18,3

Etzkowitz, H., \& Leydesdorff, L. (2000). The dynamics of innovation: From national systems and "mode 2" to a triple helix of university-industry-government relations. Research Policy, 29(2), 109-123, doi: https://doi.org/10.1016/S0048-7333(99)00055-4.

Etzkowitz, H., \& Zhou, C. (2017). Innovation incommensurability and the science park. $R \& D$ Management, 48(1), 73-87, doi: https://doi.org/10.1111/radm.12266.

Farré-Perdiguer, M., Sala-Rios, M., \& Torres-Solé, T. (2016). Network analysis for the study of technological collaboration in spaces for innovation. Science and technology parks and their relationship with the university. International Journal of Educational Technology in Higher Education, 13(1), 1-12, doi: https://doi.org/10.1186/s41239-016-0012-3.

Grundel, I., \& Dahlstrom, M. (2016). A quadruple and quintuple helix approach to regional innovation systems in the transformation to a forestry-based bioeconomy. Journal of the Knowledge Economy, 7(4), 963-983, doi: https://doi.org/10.1007/s13132-016-0411-7.

Hasche, N., Höglund, L., \& Linton, G. (2019). Quadruple helix as a network of relationships: Creating value within a Swedish regional innovation system. Journal of Small Business \& Entrepreneurship, 32(6), 523-544, doi: https://doi.org/10.1080/08276331.2019.1643134.

IASP. (2015). The role of STPS and areas of innovation. Retrieved from www.iasp.ws/the-role-of-stpsand-innovation-areas

Laguna, N. E., \& Durán-Romero, G. (2017). Science parks approaches to address sustainability: A qualitative case study of the science parks in Spain. International Journal of Social Ecology and Sustainable Development (IJSESD),, 8(3), 38-55, doi: https://doi.org/10.4018/IJSESD.2017070103.

Lindberg, M., Danilda, I., \& Torstensson, B. M. (2012). Women resource centres - A creative knowledge environment of quadruple helix. Journal of the Knowledge Economy, 3(1), 36-52, doi: https://doi. org/10.1007/s13132-011-0053-8.

Lombardi, P., Giordano, S., Farouh, H., \& Yousef, W. (2012). Modelling the smart city performance. Innovation: The European Journal of Social Science Research, 25(2), 137-149, doi: https://doi.org/ 10.1080/13511610.2012.660325.

McAdam, M., Miller, K., \& McAdam, R. (2016). Situated regional university incubation: A multilevel stakeholder perspective. Technovation, 50-51, 69-78, doi: https://doi.org/10.1016/j. technovation.2015.09.002.

Machado, A., Silva, A. R. L., Borba, M. L., \& Catapan, A. H. (2015). Habitats de inovação: Possibilidades sustentáveis para a sociedade. Proceedings of the XXV Conferência Anprotec de Empreendedorismo e Ambientes de Inovação (p. 19), Cuiabá, MT.

Machado, H. V., Lazzarotti, F., \& Bencke, F. F. (2018). Innovation models and technological parks: Interaction between parks and innovation agents. Journal of Technology Management \& Innovation, 13(2), 104-114, doi: https://doi.org/10.4067/S0718-27242018000200104.

Mineiro, A. A. C., Castro, C. C., \& Amaral, M. (2019). Quem são os atores da hélice quádrupla e quíntupla? Casos múltiplos em parques científicos e tecnológicos consolidados. Proceedings of the XXII Seminários de Administração (SemeAd), São Paulo, SP.

Mulyaningsih, H. D. (2015). Enhancing innovation in quadruple helix perspective: The case of the business incubators in Indonesia. International Business Management, 9(4), 367-371, doi: https://doi.org/10.36478/ibm.2015.367.371.

Nordberg, K. (2015). Enabling regional growth in peripheral non-university regions - The impact of a quadruple helix intermediate organization. Journal of the Knowledge Economy, 6(2), 334-356, doi: https://doi.org/10.1007/s13132-015-0241-z.

Pascoal, A., \& Cabrita, M. R. (2016). Innovation ecosystems centered in EU-based science parks: Recent past and new trends. Proceedings of the 4th International Conference on Innovation and Entrepreneurship (ICIE) (pp. 367-373). Toronto.

Russell, C. L. (2005). An overview of the integrative research review. Progress in Transplantation, 15(1), 8-13, doi: https://doi.org/10.1177/152692480501500102. 
Schoonmaker, M. G., \& Carayannis, E. G. (2013). Mode 3: A proposed classification scheme for the knowledge economy and society. Journal of the Knowledge Economy, 4(4), 556-577, doi: https:// doi.org/10.1007/s13132-012-0097-4.

Whittemore, R., \& Knafl, K. (2005). The integrative review: Updated methodology. Journal of Advanced Nursing, 52(5), 546-553, doi: https://doi.org/10.1111/j.1365-2648.2005.03621.x.

Yoon, J., Yang, J., \& Park, H. (2017). Quintuple helix structure of Sino-Korean research collaboration in science. Scientometrics, 113(1), 61-81, doi: https://doi.org/10.1007/s11192-017-2476-x.

Zouain, D. M., Damião, D., \& Catharino, M. (2005). Urban technology parks model as instrument of public policies for regionallocal development: Technology Park of Sao Paulo. Proceedings of the XXII IASP - World Conference on Science and Technology Parks, Beijing. Retrieved from www. iaspbeijing2005.com/index_1.asp

\section{Corresponding author}

Andrea Ap da Costa Mineiro can be contacted at: andreamineiro@uol.com.br

Associate editor: Rodrigo Franco Gonçalves

For instructions on how to order reprints of this article, please visit our website: www.emeraldgrouppublishing.com/licensing/reprints.htm Or contact us for further details: permissions@emeraldinsight.com 